\title{
Effects of Hip-hop Music on Students of Delta State University, Abraka, and College of Education, Warri
}

\author{
Marian Edohan Chukwuma \& Agatha Onwuekwe \\ https://dx.doi.org/10.4314/ujah.v22i2.8
}

\section{Abstract}

Since the late 1980s, Hip-hop music has passed through many stages of development and become an established musical genre of the popular music style in Nigeria. Mainly used for entertainment and satirical purposes against the excesses of the military government at the time, the performance practice, lyrical content, and use of costumes has significantly changed over the years. As a sonic and visual art, music has the ability to influence individuals and exude different emotions in humans. It is in this connection that the paper seeks to investigate and unravel some of these influences and effects that hip hop music has had on undergraduate students in Delta State University, Abraka, and College of Education, Warri. The authors relied on interviews and questionnaires as tools, while observation and analytical methods were applied in data gathering. Findings from the research reveal. The findings of the research work is that the youth are the major consumers of hip-hop music and prevalent contents in the lyrics and video in hip-hop songs have illicit contents with sex, seductive dances and immodest dressings (nudity) being more prevalent most especially the female gender prefers wanting to be famous artist by portraying some immoral attitudes that causes harm to the society which enable the genre gain unprecedented popularity and patronage, some negative impacts are palpable especially on the lifestyle of undergraduates in Delta State. It is true that the reality of modernism has become tangible in various aspects of Nigerian culture. That 
notwithstanding, unacceptable moral behaviours must not be promoted in the guise of modernism. It is therefore recommended that modernism be embraced but in line with the ethos of decency in language, communication and fashion that are characteristic of Nigerian traditional societies.

\section{Keywords: Music, Hip Hop, Undergraduates, Tertiary Institution}

\section{Introduction}

Hip-Hop is a stylized and highly rhythmic musical genre that sometimes accompanies rapping in rhyming speech that is often chanted; it is generally accepted by contemporary society and highly patronized in social orbits. Okafor $(1994$, p. 98), explains that it is music of old and new which appeals to the mass audience, which does not require guided listening as a result of the familiarity with the idioms of the people and their being quite receptive to it. Hip-hop music has evolved into a culture of its own in society, and has captivated the minds of contemporary Nigerian youths. This is partly because youths are the ones mostly used as props for the illusive lifestyle portrayed in several Hip-Hop music videos. The hip-hop culture, as seen in music videos has become influential on youths with sometimes strong promotion of sexuality through the lyrics. Thus, there appears to be a gross modification of some values among students in tertiary institutions on the lifestyle they exhibit which deviates from acceptable communal values and generally accepted customary norms as a result of the influences from this genre of music and its videos. These deviations from the accepted societal norms and behavior are noticeable in the mode of dressing, psychological and mental instability of most students, 
because of the vulgar, loud, violent and aggressive lyrics that glorify nudity, sex and violence. It is against this background that the study aims to identify the effects of hip-hop music on students in two tertiary institutions in Delta State, Nigeria, and create awareness of the negative effects of some hip-hop music on them. Findings from the study will bring to the notice of the music industry and media that, continued exposure to certain unregulated hip-hop music videos could damage the psychic state and academic wholeness of students, thereby causing harm to society in the long run. It will also draw the attention of relevant agencies like censorship boards on the need to regulate public exhibition of musical videos.

\section{Research Questions}

The following research questions were formulated to guide the study:

1. What are the positive and negative effects of hip-hop music on students in tertiary institutions?

2. What are the prospects and problems of hip-hop music to the music industry in the society?

3. What are the suggested solutions to the effects of hip-hop music on students?

\section{Scope of the Study}

The study was carried out in two tertiary institutions in Delta State, Nigeria. The institutions are: Delta State University Abraka and College of Education, Warri. The aim was to assess the effects of hip-hop music on students in the selected institutions, and possibly 
ascertain potential ways of curbing some of the negative effects of hip-hop music on students.

\section{The Concept of Music}

Glennon $(2017$, p. 2) simply defines music as an "expression of sound" or the expression of thoughts and feelings in an aesthetic way. Onwuekwe (2004. P. 74) asserts that music has been styled the greatest of the arts. She added all sound is music. This means that the major component of music is sound. According to Gluck (2005, p. 116), music can be reduced to its main feature invisibility, technically and socially, cognitive and commercially. Music as a technically invisible construct has a direct effect on other sensorial organs than visible information.

Effiong (2009, p. 114) views music as 'one of the fine arts which is concerned with the combination of views, beauty of form and expression of feelings or thoughts. Esimone (2012, p. 10) asserts that music is embedded with a strong power to transform, influence and affect the life of people all over the world irrespective of position, color, race or gender. It unarguably enjoys the place of the most influential form of art. Music is a communicative activity which conveys moods, emotions, thoughts, and impressions, philosophical or political concepts to the listener, because of its ability to communicate.

\section{Hip-Hop Music}

Hip-hop is a broader term used to describe a culture which rap music is part of. Okafor (1994, p. 98), explains that it is music of old and new which appeals to the mass audience, which does not require guided listening as a result of the familiarity with the idioms to the people and their being quite receptive to it. Hip-hop as a style 
rooted predominantly in soul, disco and funk music while the beats and thematic music are usually repeated for the duration of the tracks. Omibiyi (1994, p. 12) describes pop music to be a musical genre that has wide appeal and is typically distributed to large audiences through the music industry. It stands in contrast to both art and traditional music which are typically disseminated academically and orally to a large audience. Alim, (2006) believes that the hip-hop music genre denotes the practice of the entire subculture which consists of intensely rhythmic lyrical form making abundant use of techniques like assonance, alliteration and rhyme accompanied by an instrumental track usually referred to as a "beat" with cultural movement that includes the activities of break dancing and graffiti art as well as associated slangs, fashion and other element which is built on people's idea and view. (p.65). Hip-hop music is highly varied, it includes patriotic and political songs, folk music instrumental pieces, rock and rap music etc., within the public parlance which refers to western orientation that involves a heavy rhythmic turntable wizardry, drum machines, sampling and rap.

These days the hip-hop community is growing online, led by social network video sites like Rap space, television, modern rap often contains lyrics which make it popular with the youths primarily because of the choice of vocabulary and the issues it addresses often relating to modern day problems and suffering which the listener can relate to. Summarily, hip-hop music genre deals with familiar themes that encompass several styles that is readily comprehensible to a large proportion of the population. It is understood and accepted by a lot of people not as a final solution 
to their problems but as a topical reflection of their sentiment and current world view.

\section{Theoretical Framework}

Transformative musicology was developed by Adedeji (2010). The theory postulates that music could be used as a vehicle of transformative processes needed in our society and that musical composition constitutes its major tool. The ambivalent nature of the power of music was demonstrated in the theory, in which the author enumerated that hip-hop musician need to start creating songs that are more educative and morally balanced in nature by recontextualizing their themes and making them free from profane language and sexual attribute in order to meet contemporary social challenges and conclude on the urgent need to compose music that prognosticates into the future by focusing on transformative theme. Having examined the theory, the summary and implication is that youths who imitate negative attitude can be transformed if the right music which possesses the anabolic function is composed. Adedeji's theory raises an important point that is very critical in this study. If the students were likely to imitate actions through the lyrics and composition of music that is heard or watched, that music could be used as a vehicle of transformation process in the society for societal change; so as to avoid violence, crime and drug abuse. The relevance of transformative musicology theory to the study is that apart from the negative effects of hip-hop music genre, it can also serve as a transformative function in influencing the youths positively because alternate genre of music that are related can be composed with educative themes that will pass positive messages to the listeners. 


\section{Primary Mediums of Streaming Hip-Hop Music}

Television. Television as a medium of communication has become popular, as youth programmes are very common. Several television shows portray sexual behavior which include music with morally inappropriate content. Television has the potential to generate both positive and negative effects and its influence on youths is related to how much time they spend watching television.

Movies: Movies are another form of media that is admired by youths, especially those that contain scenes where characters like violent or sexual acts are displayed. The scene can be on aggressive behavior (i.e robbery, homicide, or rape) or early sexual intercourse.

Music Videos : Most Hip-Hop music videos have a negative behavioral impact on youths, because precursory observation by the authors show that about $75 \%$ of music videos aired on cable TV stations contain sexually explicit material or messages in songs which can influence attitudes and behaviors. Youths are likely to copy or emulate the musician or the acts as social learning indicates that this messages may be internalized and later expressed as behavior, whether socially desirable or undesirable.

Mobile Phones: Mobile phones became common around 2003 in Nigeria. With the introduction of new social networks like Twitter, Whatsapp, Facebook, and Instagram, students can communicate or send sexual messages, pornography pictures which they sourced 
from the internet to their counterparts. Thereby promoting and initiating early sexual activity among themselves.

The reliable parameter to measure the correlation between hip-hop music and the perceived illicit behavior among youths was based on observation of students during social event, interview, questionnaire and some empirical review of different authors of works related to the article

Idolor, (2002). Stated that: "The influence of love and sex on hip-hop music in recent times has been overwhelming. He further buttressed this affirmation by saying that the society has not been spared the consequences of this misplacement, if not abuse, of such delicate and sensitive aspects of social life and has contributed to illicit sex, unwanted pregnancies, broken homes and relationships, unhappiness and inhuman desires in different societies" (p.23). Okeke, (2009) also investigated on a similar topic. The title of his study was the impact of pop-music on Nigerian youths: A case study of Nnamdi Azikiwe University, Awka undergraduate.The researcher stated that he could not sample as much data and opinion of the undergraduates as intended because of students rush to lectures and unwillingness in giving out information as they see it as betrayal of their secret. Some of his findings include that pop music induces strong desires for sex, contributions to loss of spiritual power and poor academic performance. Research has indicated that there is a Strong link between exposure of sexual music and sexual activity Forbes (2010), however, said that popular music does influence the students' sexual attitudes, feelings, and sexual behavior. 


\section{Method of Data Collection and Analysis}

Data for the study were collected through questionnaires. The questionnaire was administered to respondents by the researchers and their assistants. Copies of the questionnaires were retrieved after they were completed. The direct administration method adopted by the researchers afforded them the opportunity to ensure that all the respondents issued with the instrument returned same. At the end of the day, all the copies of the questionnaires issued were completed and duly returned.

The research questionnaire was designed in four-point Likert scale and was analyzed using the mean. The mean and percentage score for each questionnaire item was obtained by multiplying the frequency of each response on each categories with the appropriate nominal values assigned to them and dividing each by the total number of subjects that responded to the questionnaire item. The formula used in the analysis is shown below:

\begin{tabular}{|l|l|l|l|}
\hline $\begin{array}{l}\text { Strongly } \\
\text { Agree }\end{array}$ & $\begin{array}{l}\text { Agree } \\
\text { (A) }\end{array}$ & $\begin{array}{c}\text { Disagree } \\
\text { (D) }\end{array}$ & $\begin{array}{c}\text { Strongly } \\
\text { Disagree } \\
\text { (SD) }\end{array}$ \\
\hline 4 points & 3 points & 2 points & 1 point \\
\hline
\end{tabular}

$$
\mathrm{X}=\frac{\sum f x}{\mathrm{~N}}
$$

Where $\Sigma=$ Summation

$$
\begin{aligned}
& \mathrm{X}=\text { Total points scored } \\
& \mathrm{X}=\text { Mean }
\end{aligned}
$$




$$
\begin{aligned}
f & =\text { Frequency responses. } \\
\mathrm{n} & =\text { Total number of responses. }
\end{aligned}
$$

\section{What are the positive effects of hip-hop music on the students?}

Table 1: Positive effects of hip-hop music on female students in

\begin{tabular}{|c|c|c|c|c|c|c|c|c|c|}
\hline \multirow{2}{*}{$\begin{array}{l}\text { S/ } \\
\text { n }\end{array}$} & \multirow{2}{*}{$\begin{array}{l}\text { Description of } \\
\text { Questionnaire } \\
\text { Item }\end{array}$} & \multicolumn{4}{|c|}{ Responses } & \multicolumn{4}{|c|}{ Interpretations } \\
\hline & & 9 & $\mathbf{A}$ & D & SD & $\begin{array}{l}\text { No.o } \\
\text { f } \\
\text { Resp }\end{array}$ & $\mathbf{X}$ & - & Decision \\
\hline 1. & $\begin{array}{l}\text { Hip-hop music has } \\
\text { demonstrated a } \\
\text { great ability to } \\
\text { unify youths } \\
\text { around the world }\end{array}$ & 286 & 222 & 46 & 26 & 580 & 1928 & 3.3 & Agreed \\
\hline 2. & $\begin{array}{lr}\text { Hip-hop music } \\
\text { educates youths } \\
\text { on how to foster } \\
\text { moral, social } \\
\text { activities and } \\
\text { educational } \\
\text { developments in } \\
\text { tertiary } \\
\text { institutions }\end{array}$ & 300 & 168 & 82 & 30 & 580 & 1898 & 3.3 & Agreed \\
\hline
\end{tabular}

Delta State University, Abraka and College of Education, Warri. 


\begin{tabular}{|c|c|c|c|c|c|c|c|c|c|}
\hline 3. & $\begin{array}{l}\text { Hip-hop has the } \\
\text { ability of bringing } \\
\text { messages to the } \\
\text { masses such as } \\
\text { creating } \\
\text { awareness on } \\
\text { issues that are } \\
\text { happening in } \\
\text { society. }\end{array}$ & 320 & 150 & 60 & 50 & 580 & 1900 & 3.3 & Agreed \\
\hline 4. & $\begin{array}{l}\text { Hip-hop music has } \\
\text { an effective role in } \\
\text { benefiting the } \\
\text { people, most } \\
\text { especially the } \\
\text { youths in tertiary } \\
\text { institution and } \\
\text { society at large. }\end{array}$ & 268 & 224 & 48 & 40 & 580 & 1880 & 3.2 & Agreed \\
\hline 5. & $\begin{array}{l}\text { Hip-hop music } \\
\text { ignites the interest } \\
\text { of the youths. }\end{array}$ & 264 & 194 & 86 & 33 & 580 & 1859 & 3.2 & Agreed \\
\hline 6. & $\begin{array}{l}\text { The benefits of } \\
\text { hip-hop music } \\
\text { helps in promoting } \\
\text { social, political } \\
\text { awareness among } \\
\text { youths in the } \\
\text { tertiary institution. }\end{array}$ & 204 & 266 & 66 & 44 & 580 & 1846 & 3.2 & Agreed \\
\hline & & & & & & & & & \\
\hline
\end{tabular}


Weights and class limits of the 4 likert Scale

\begin{tabular}{|c|c|c|}
\hline $\begin{array}{l}\text { Response } \\
\text { Option }\end{array}$ & Weight & $\begin{array}{l}\text { Class } \\
\text { Limit }\end{array}$ \\
\hline Strongly Agree & 4 & $3.5-4.49$ \\
\hline Agree & 3 & $2.5-3.49$ \\
\hline Disagree & 2 & $1.5-2.49$ \\
\hline Strongly Disagree & 1 & $0.5-1.49$ \\
\hline & & \\
\hline
\end{tabular}

Table1: Above is the presentation of the respondents' opinion on the negative effects of hip-hop music on young female undergraduates. The extent to which respondents agree or disagree with the statement in the items was determined by the value of their mean score.

Item 1: As could be seen from the table, seventy percent (70\%) strongly agree, to the statement that hip-hop music has demonstrated a great ability to unify youths around the world, twenty percent (20\%) agreed, ten percent (10\%) disagreed and five percent $(5 \%)$ strongly disagreed with the statement, with a mean score of 3.4 .

Item 2. Analysis of the respondents' opinion on item 2 reveals that sixty percent $(60 \%)$ strongly agree with the statement that hip-hop music educates youths on how to foster moral, social activities and educational development in the society, twenty percent (20\%) agreed, fifteen percent (15\%) disagreed while five percent $(5 \%)$ strongly disagree with the statement with a mean score of 3.3. 
Item 3. Table 3 shows that sixty-five percent (65\%) strongly agree with the statement that hip-hop music has the ability of bringing messages to the masses such as creating awareness of issues that are happening in the country, twenty-five percent (25\%) agreed, seven percent (7\%) disagreed while three percent (3\%) strongly disagreed. With a mean score of 3.3. This implies that majority of the respondents believe that hip-hop music creates awareness on issues that are happening in the country through information in its messages.

Item 4. The analysis of the respondent's opinion on item 4 reveals that forty percent (40\%) strongly agreed that hip-hop music has an effective role in benefiting the people most especially the youths in tertiary institution and society at large. Forty-five percent (45\%) agreed, ten percent (10\%) disagreed, while five percent 5\% strongly disagreed with the statement. The mean score was 3.2. From this analysis as could be seen, respondents agreed with the statement.

Item 5. As can be seen on item fifty percent (50\%) strongly agreed with the statement that hip-hop music ignites the interest of the youths, twenty-five percent $(25 \%)$ agreed, four percent $(4 \%)$, disagreed while five percent $(5 \%)$ strongly disagreed with the statement. The mean score was 3.2. From this analysis, most respondents believed that hip-hop music ignites the interest of the female.

Item 6. The analysis of the respondent's opinion on item 6 reveals that seventy percent (70\%) strongly agreed that the benefit of hiphop music helps in promoting social, political awareness among 
youths in the tertiary institution, twenty percent (20\%) agreed, six percent $(6 \%)$ disagreed while four percent (4\%) strongly disagreed with the statement. The mean score was 3.2. From this analysis, the respondents strongly agreed that the benefits of hip-hop music help in promoting social, political awareness among female. From the analysis, sixty percent (60\%) respondents agree to the fact that Hiphop music helps improve social consciousness by increasing awareness of issues that many youths face today.

From table 1, the mean ratings and percentage of the respondents show that youths strongly agree with all the statements but specific consideration indicated that they also agree others. For instance, the youths strongly agreed with items $1,4,5$, and 6 , while they agreed with item 2,3 , and 7 . An outright agreement with such a statement means they accepted the fact that the prospect of Nigerian hip-hop music in the society has it positive ways of contributing to the youths in tertiary institutions.

\section{Research Question (RQ2)}

What are the negative effects of hip-hop music on Students in tertiary institutions? 
Table 2: The perception of youths on the negative effects of hiphop music on students in tertiary institutions

\begin{tabular}{|c|c|c|c|c|c|c|c|c|c|}
\hline \multirow[t]{2}{*}{$\mathbf{S} / \mathbf{n}$} & \multirow{2}{*}{$\begin{array}{l}\text { Description of } \\
\text { Questionnaire Item }\end{array}$} & \multicolumn{4}{|c|}{ Responses } & \multicolumn{4}{|c|}{ Interpretations } \\
\hline & & SA & $\mathbf{A}$ & D & SD & $\begin{array}{l}\text { Nos. } \\
\text { of } \\
\text { Resp }\end{array}$ & $\mathbf{X}$ & - & Decision \\
\hline 1 & $\begin{array}{l}\text { Hip hop music has } \\
\text { been a catalyst to } \\
\text { problems such as teen } \\
\text { pregnancy, criminal } \\
\text { actions such as } \\
\text { warfare, negative gang } \\
\text { formation and fight in } \\
\text { the tertiary institution }\end{array}$ & 320 & 170 & 70 & 30 & 580 & 1940 & 3.3 & Agreed \\
\hline 2. & $\begin{array}{l}\text { Hip-hop music has } \\
\text { made the female } \\
\text { youths get involved in } \\
\text { abortions ,rape cases, } \\
\text { indecent dressing, } \\
\text { domestic abuse and } \\
\text { sexual assault in the } \\
\text { tertiary institution }\end{array}$ & 264 & 194 & 86 & 33 & 580 & 1945 & 3.4 & Agreed \\
\hline 3. & $\begin{array}{l}\text { Lyrical lines of hip } \\
\text { hop music have } \\
\text { negative influence on } \\
\text { the youths in the } \\
\text { tertiary institution }\end{array}$ & 230 & 224 & 78 & 48 & 580 & 1796 & 3.1 & $\begin{array}{l}\text { Strongly- } \\
\text { Agreed }\end{array}$ \\
\hline 4 & $\begin{array}{lr}\text { Hip hop } & \text { music } \\
\text { promotes immoral } \\
\text { behaviour } \\
\text { teenagers in the } \\
\text { tertiary institution }\end{array}$ & 258 & 208 & 76 & 38 & 580 & 1852 & 3.2 & Agreed \\
\hline 5 & $\begin{array}{l}\text { Hip hop music has } \\
\text { been a landmark } \\
\text { influence on the } \\
\text { youths negatively in }\end{array}$ & 204 & 170 & $\begin{array}{l}19 \\
0\end{array}$ & 13 & 580 & 1659 & 2.8 & Agreed \\
\hline
\end{tabular}




\begin{tabular}{|l|l|l|l|l|l|l|l|l|}
\hline & $\begin{array}{l}\text { the way they dress, } \\
\text { talk and act in the } \\
\text { tertiary institution. }\end{array}$ & & & & & & & \\
\hline 6. & $\begin{array}{l}\text { Hip hop culture such } \\
\text { as gangsta rap is a } \\
\text { sub-genre of hip-hop } \\
\text { that focuses on the } \\
\text { violent and destitute } \\
\text { conditions have a } \\
\text { negative impact on the } \\
\text { attitudes of youths in } \\
\text { the tertiary institution }\end{array}$ \\
7. & $\begin{array}{l}\text { Hip hop music } \\
\text { influences negatively } \\
\text { the lifestyle of the } \\
\text { youths by getting } \\
\text { involved in sexual } \\
\text { exploitation, violence, } \\
\text { drugs taking which a } \\
\text { times leads to drug } \\
\text { abuse. }\end{array}$ & 178 & 74 & 46 & 580 & 1856 & 3.2 & Agreed \\
\hline
\end{tabular}

Table 2 Above is the presentation of the respondents' opinion on the negative effects of hip-hop music on the female undergraduates in tertiary institutions. The extent to which respondents agreed or disagreed with the statement in the items was determined by the value of their mean score.

Item 1: From the table, fifty percent (50\%) strongly agreed to the statement that hip-hop music has been a catalyst to problems such as teen pregnancy, criminal actions such as warfare, negative gang formation and fight in the tertiary institution, thirty percent (30\%)agreed, fifteen percent $(15 \%)$ disagreed and five percent $(5 \%)$ strongly disagreed with the statement, with a mean score of 
3.3. It is worth mentioning here that the higher percentage strongly agreed with the statement.

Item 2. The analysis of the respondents' opinion on item 2 reveals that sixty percent $(60 \%)$ strongly agreed with the statement that hip-hop music made the female youths get involved in rape cases, indecent dressing, domestic abuse and sexual assault in the tertiary institution, twenty-five (25\%) agreed, ten percent (10\%) disagreed while five percent $(5 \%)$ strongly disagreed with the statement with a mean score of 3.4 .

Item 3. Table 3 shows that sixty percent (60\%) strongly agreed with the statement that the lyrical lines of hip-hop music have negative influence on the youths in the tertiary institution, twentyeight percent $(28 \%)$ agreed, seven percent $(7 \%)$ disagreed while five percent (5\%) strongly disagreed. With a mean score of 3.1. This implies that majority of the respondents Agreed to the statement.

Item 4. The analysis of the respondent's opinion on item 4 reveals that sixty percent $(60 \%)$ strongly agreed that hip-hop music promotes immoral behavior on female in the tertiary institution. twenty-five percent (25\%) agreed, five percent $(5 \%)$ disagreed, while ten percent $(10 \%)$ strongly disagreed with the statement. The mean score was 3.2. From this analysis as could be seen respondents strongly agreed with the statement.

Item 5. As could be seen on item seventy percent (70\%) strongly agreed with the statement that hip-hop music has impacts on the youths negatively in the way they dress, talk and act in the tertiary 
institution, twenty percent (20\%) agreed, ten percent (10\%) ,disagreed while five (5\%) strongly disagreed with the statement. The mean score was 2.8 . From this analysis, $70 \%$ strongly agreed to the statement.

Item 6. The analysis of the respondent's opinion on item 6 reveals that fifty percent $(50 \%)$ strongly agreed that hip-hop such as gangsta rap have negative impact on the attitudes of female in the tertiary institution, twenty-five percent $(25 \%)$ agreed, fifteen percent $(15 \%)$ disagreed while ten percent (10\%) strongly disagreed with the statement. The mean score was 3.4. From this analysis, the respondents strongly agreed to the statement.

Item 7. The analysis of the respondents' opinion on item 7 reveals that forty percent (40\%) strongly agreed that hip-hop music negatively influenced the life-style of the female by getting them involved in sexual exploitation, violence, drugs taking, thirty-five percent $(35 \%)$ agreed, seventeen percent $(17 \%)$ disagreed while eight (8\%) strongly disagreed with the statement. The mean score was 3.2. As could be seen on the analysis, forty percent (40\%) respondents strongly agreed to the statement.

As could be seen from Table 2, the mean ratings and percentage of the respondents shows that the youths agreed with all the statements but specific consideration indicated that they strongly agreed with some and merely agreed with others. For instance, the female agreed with items 1,2,4,6 and 7, while they strongly agreed with item 3 and 5 . An outright agreement with such a statement means they accepted the fact that hip-hop music is good but it problems and influences on youths should be examined by 
the listeners so as to avoid being part of those who contribute and cause the problems.

\section{Analyses of some Nigerian Hip-hop Music with Vulgar Contents}

Some of the musical works of Olamide, Timaya and Brymo project vulgar languages in their theme, as reflected in the song "story for the gods" by Olamide, "bum bum" by Timaya and Prick no get shoulder by Brymo, Nwa Baby by Flavour.

\section{ANALYSIS OF THE SONG "Bum Bum".}

\section{Bumbum}
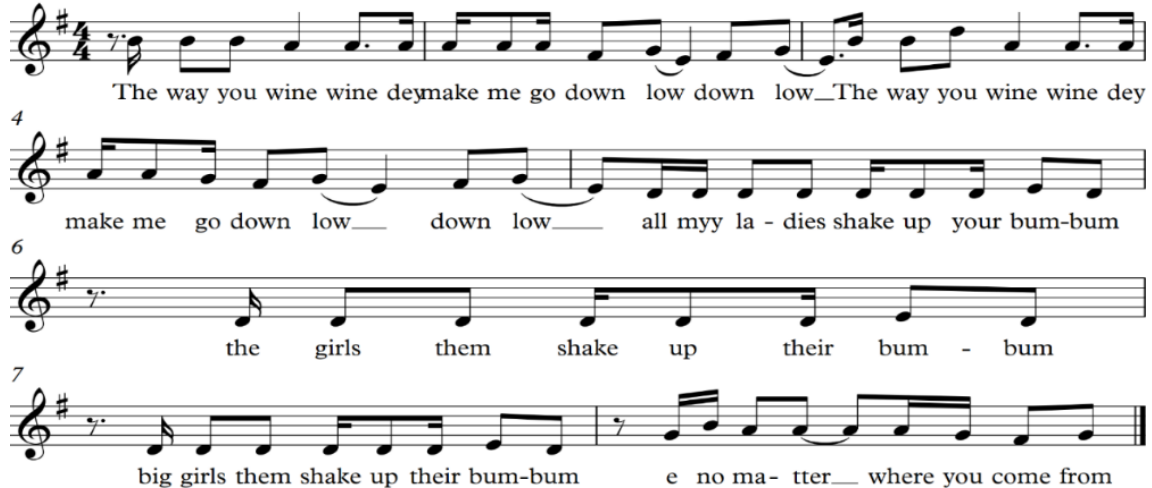


\begin{tabular}{|l|l|}
\hline Lyrics & Meaning \\
\hline The way you wine wine & The way you twist \\
\hline Dey make me go down low o & Makes me go down \\
\hline $\begin{array}{l}\text { All the ladies shake your bum } \\
\text { bum }\end{array}$ & $\begin{array}{l}\text { All the ladies shake your } \\
\text { buttocks }\end{array}$ \\
\hline $\begin{array}{l}\text { The girls dem sey shake their } \\
\text { bum bum }\end{array}$ & The girls shake their buttocks \\
\hline $\begin{array}{l}\text { Big girls dey shake their bum } \\
\text { bum }\end{array}$ & Big girls shake their buttocks \\
\hline $\begin{array}{l}\text { E no matter where you come } \\
\text { from }\end{array}$ & $\begin{array}{l}\text { It doesn't matter where you are } \\
\text { from }\end{array}$ \\
\hline
\end{tabular}

This above song by Timaya is about ladies twisting their buttocks. The slogan "shake up your bum bum" means "twist your buttocks" which is a recurring phrase all through the song. He encourages every lady to twist their buttocks regardless of where they come from and not putting into consideration the male folks who are susceptible to receiving the direct impact of the "twist" 


\section{ANALYSIS OF THE SONG "NWA BABY" BY FLAVOUR- Song 2}

\section{Nwa Baby}

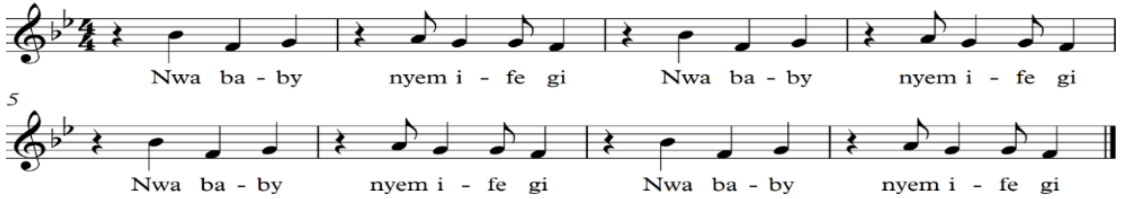

\begin{tabular}{|l|l|}
\hline LYRICS & MEANING \\
\hline Nwa baby, nye me fege & $\begin{array}{l}\text { Baby Girl give me your } \\
\text { vagina }\end{array}$ \\
\hline Nwa baby, o kwa Nabania & $\begin{array}{l}\text { Baby Girl, is this night u will } \\
\text { give me }\end{array}$ \\
\hline $\begin{array}{l}\text { Baby Girl, is this night u will } \\
\text { give me }\end{array}$ & $\begin{array}{l}\text { Someone say it will happen } \\
\text { this night }\end{array}$ \\
\hline Na takwa ne fe omo wania & $\begin{array}{l}\text { Please lets chop money and } \\
\text { enjoy See the girls them } \\
\text { plenty }\end{array}$ \\
\hline $\begin{array}{l}\text { I go tell my mama, (oh yeah) I } \\
\text { go }\end{array}$ & 1 will tell my mama \\
\hline Tell my papa (oh yeah) & $\begin{array}{l}\text { Woman tell my Papa } \\
\text { waist }\end{array}$ \\
\hline Ojari kpokpo, ukwu nwa baby & $\begin{array}{l}\text { Shake your waist, shake it } \\
\text { well }\end{array}$ \\
\hline Achukwu rege, kpom kpom & Prostitute - Harlot \\
\hline Ashawo, awusha 208 \\
\hline \multicolumn{2}{|c}{} \\
\hline
\end{tabular}




\begin{tabular}{|c|c|}
\hline $\begin{array}{l}\text { Na like so I go dey waka all the } \\
\text { time }\end{array}$ & $\begin{array}{l}\text { All the time I move } \\
\text { about }\end{array}$ \\
\hline Everywhere I go, anai ti fe & $\begin{array}{l}\text { Anywhere I go, I eat money, } \\
\text { all eat Woman Vagina }\end{array}$ \\
\hline All my guys where una dey & All my friends where are you \\
\hline From here to saloon hotel & $\begin{array}{l}\text { We all move from hair to } \\
\text { Hotel }\end{array}$ \\
\hline Ala mama & If the female breast is fine \\
\hline Wera kagi ji de ala & 1 will hold it with my hand \\
\hline Ala mama & $\begin{array}{l}\text { if the breast is fine and } \\
\text { standing }\end{array}$ \\
\hline Wero noge me jaya ala & $\begin{array}{l}1 \text { will use my mouth and suck } \\
\text { it }\end{array}$ \\
\hline Sawa sawa baby & Spoilt baby \\
\hline Corner corner baby & Corner baby \\
\hline Kpokpotom kpakolo kpa & (Making sound) \\
\hline
\end{tabular}

This song by Flavour is all about female gender. He used the lyrical theme of the song to objectify the vital part of the female gender which is a recurring phrase all the through the song. 


\section{ANALYSIS OF THE SONG "Prick no get shoulder" Song 3 \\ Prick no get shoulder}
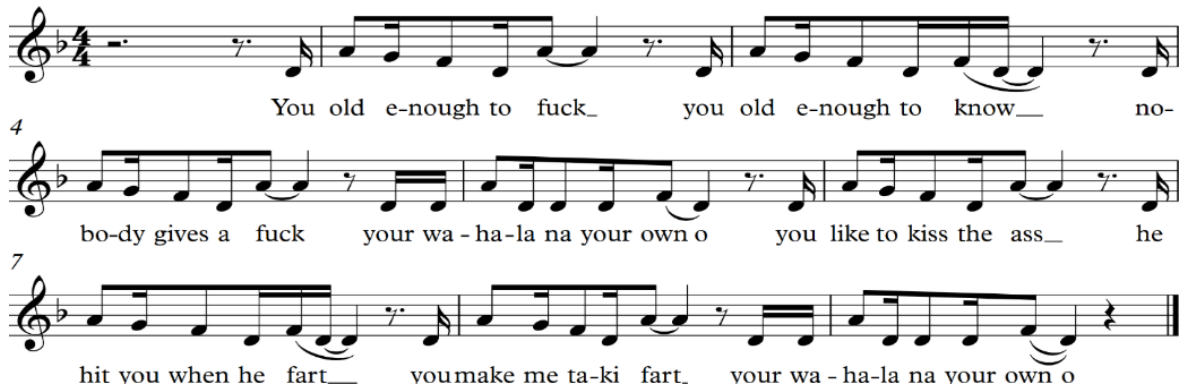

hit vou when he fart__ voumake me ta-ki fart_ vour wa - ha-la na vour own o

\begin{tabular}{|l|l|}
\hline Lyrics & Meaning \\
\hline You old enough to fuck & You old enough to have sex \\
\hline You old enough to know & You are old enough to know \\
\hline Nobody give a fuck & Nobody cares \\
\hline Your wahala na your own & Your problems is yours \\
\hline He hits you when he fart & $\begin{array}{l}\text { He hit you when he pollute the } \\
\text { air }\end{array}$ \\
\hline You take am take fart & You just take it like that \\
\hline Your wahala na your own & Your problem is yours \\
\hline If e sweet o & If sex is sweet \\
\hline I go chop slow slow & If will take it gently \\
\hline Awuf dey purge o & There is a price for everything \\
\hline No talk say you no no & Don't say you don't know \\
\hline To say no na reason & To refuse sex is for a reason \\
\hline
\end{tabular}




\begin{tabular}{|l|l|}
\hline To say yes na prison & To accept it to be caged \\
\hline Hear me so & Listen to me \\
\hline I dey scream am o & I am shouting it \\
\hline
\end{tabular}

\begin{tabular}{|l|l|}
\hline Prick no get shoulder & The penis has no shoulder \\
\hline $\begin{array}{l}\text { You put the head the rest } \\
\text { enter }\end{array}$ & You put the head the rest enters \\
\hline $\begin{array}{l}\text { For this world wetin you } \\
\text { chop }\end{array}$ & $\begin{array}{l}\text { In this world what you sow you } \\
\text { reap }\end{array}$ \\
\hline Na tru tin nah in I talk & What I say is the truth \\
\hline
\end{tabular}

This song "Prick no get shoulder" by Brymo has raised some controversies. Brymo received a message from one of his fans on his twitter page asking him the meaning of the song, his reply was that the music talks about abstinence from sex. In as much as there are moral lessons in this song, the vulgar lyrical content seems to overshadow it.

\section{Analyzing the Influence of Hip-hop Music}

According to Travis (2011), hip-hop music has been a vehicle for affirming one's identity, and serves as a pathway to become popular internationally (p. 139). With hip hop having such a huge influence on people around the world, the content and lyrics help develop one's perception. A known criticism within hip-hop music includes the amount of misogyny presented in lyrical content. Misogyny is defined as "the ideology that reduces women to objects for men's ownership and abuse". Hip-hop music has the power to influence the mental state of consumers positively and negatively. Hip-hop music has a negative connotation because the 
content includes sex, drugs and violent content. The greatest concern of this content within hip-hop music has been because of the high risk of morbidity and mortality associated with violent or substance using behaviors.

In a recent study, Travis (2011) notes that hip-hop music now includes innovation from environments of injustice and oppression he also noted that hip hop has become universal because of the message most artistes convey within their music. (p. 142).

Hip hop consumer base consists of multiple ages, but it primarily appeals to the younger generation. Many youths view hip hop as a recognizable media where they can feel valued and validated to freely express themselves while singing. Listening to hip-hop music can serve as a therapeutic process for people. Music engagement has proven to facilitate emotional regulation. Adolescents and adults use music to promote a positive mood, reduce negative moods, or even trigger nostalgia to help them mentally. Hip hop artistes use lyrics and celebrity status to relay an influential message to consumers of hip hop. Visuals have a greater effect on influencing consumers of media and music.

In a recent study by Tanner and Worley (2016), hip-hop music is often framed negatively as a contribution to an array of social problems, crime, and delinquency. But hip-hop music has also been championed as an authentic expression of cultural resistance, advantages, and racial exploitation (p.12).

Hip hop influence has played a part in multiple outlets such as, sports, politics, education and more. Most lyrics in hip hop are harsh realities from these artistes, they speak on these issues to help the younger generation avoid going down the same path, hip -hop can play a positive or negative role in students' lives. 
The life portrayed in hip-hop music videos happen in reality, but that does not mean that the consumer should reenact the actions seen in these music videos. Not every music video portrays negative imagery; there are artists that actually use their platform to send positive, creative messages. These positive videos can have a great effect on students as well. Spradlin (2016) states that hip hop has the ability to inspire a new way of narrative self. Hip hop challenges the way people understand and view certain experiences through articulation of involvement (p. 52).

\section{Positive Influence of Hip-hop Music on Students}

It was discovered that hip-hop music is beneficial to students. It would be recalled that effort was made to demonstrate the social life of a youth and their responses to hip-hop music genre. The music genre can positively affect students, triggering happiness and excitement, it also instills confidence by developing their communicative skill. It has without a doubt uplifted certain communities, provided a voice to a group of artists attempting to deliver message. From the study, it was discovered that students constantly participate in hip-hop music which can enhance their communication. Effective communication skills are essential for the successful career of an undergraduate. Since hip-hop music deals with a lot of communication, the ability and necessity of a student to communicate different ideas in different languages is a skill that is translated into classroom and has added knowledge to the undergraduate. The hip-hop music has given students in tertiary institutions the opportunity to participate in team work which demonstrates a great ability in unifying youths around the world:

Another positive influence of hip-hop music is that it has helped reshape cultural norms and practices in the society by 
establishing new modes of conduct, learning and social interactions. The music genre has also inspired social change and attitudinal progression, it has helped develop empathic skills in some students which enable them build friendship of trust based on positive relationships among their peers. The music videos are also powerful influencers on consumers because videos add a visual representation to the lyrics which can also influence good morals in the way they behave. Over $70 \%$ of the respondents strongly agreed and indicated that the music genre also has positive effects in the lives of students most especially in the development of one's perceptions, creating awareness on events, educating and promoting social perspectives as a great unifier of diverse population around the world.

\section{The Negative Influence on Female Students.}

Due to constant exposure to hip-hop music and its videos, it is now common scenes to see great numbers of female students go almost nude in the guise of fashion. The negative repercussions of this ranges from rape, prostitution to transmission of deadly diseases.

\section{Teenage-pregnancy}

The study showed that there is a great connection between hip- pop music videos and female desire for sex. Most of what is portrayed in hip-pop music videos are things that negatively affect the mind. The female students, having been exposed to all sorts of pop music videos including the ones that emphasize gullible sex images, tend to imitate what they have seen in real life situation. Collins (2004) supported this finding when he found that teens who watched large quantities of television containing sexual content were two times 
as likely to begin having sex within the next year as teens who did not view such programming"(p.114).

\section{Uncontrolled Clubbing and Partying}

The study also showed that uncontrolled clubbing and partying associated with hip-hop music has affected the majority of the students. Though, parties are fun, there is a time line between having fun and getting out of control. Parties constitute integral part of youth culture and serves as primary settings where some many students engage in heavy drinking, thereby reducing their commitment to studies. It is quite difficult nowadays for many students to get adequate rest. This is often due to overloaded academic work and social life. And when they fail to get the rest or sound sleep needed to stay mentally alert, they experience learning difficulties. Some students may even skip classes to recover from their late nights out. A student is meant to be alert and always in class during the teaching - learning process. Where a student skips classes, it has gross implication on their performance in the school.

\section{Drug Addiction}

It has been found also from the study that some hip-hop music videos usually contain images where pop stars and artistes smoke and abuse drugs. In other words, multiple musical albums have been found to revolve around drug abusers. This has direct consequences on the students as they try to emulate the artistes not minding the resultant effects. Drug addiction is one of the juvenile challenges in Nigeria. Some research have shown that the human brain still develops until around the age of twenty-five and during this developmental stage, any type of trauma or changes in the brain wiring could affect how the it functions. According 
to the National Institute on Drugs Abuse (NIDA), the human brain relies on chemicals called neurotransmitters to get messages from one part of the brain to the other. Each neurotransmitters attaches to its own kind of receptor, like how a key fits into a lock. This allows messages travel through the brain on the right path. But when students take illicit drugs, they interfere with the normal traffic patterns that the neurotransmitters use. The chemical structures in the drugs can alter the activity of the nerve cells.

\section{Use of Earphones}

The incessant use of earphones is also one of the direct consequences of contemporary popular music genre on the students especially in an age where many students own iPods or iTunes capabilities. When we use earphones, the sound produced from our audio devices will directly hit our ear drums. Once the sound level begins to exceed the limit, damage is gradually being done to our ears. In other words, persistent use of earphones could damage students' ear drums, thereby rendering them ineffective during teaching and learning. This is the same thing as hearing loss which may not be recognized immediately but after many years, thus making treatment and intervention difficult when detected. Earphones notwithstanding, have enabled the youths and even the adults to listen to music wherever they desire, but persistent use of earphones or listening to music while studying creates huge distractions.

\section{Conclusion}

The research shows that continued exposure to hip-hop music videos will endanger the students in tertiary institutions and the 
larger society. The findings also suggest that most students seem to lack the enlightened parametric sense for critiquing, sieving and electing the sort of images they watch on social media. Although the study focused on students in tertiary institutions, younger ones in secondary and primary schools are also vulnerable to these negative influences. Therefore, parents must ensure that they enact and enforce control measures that will prevent their wards from getting exposed to illicit audio - visual content from any device.

\section{Recommendations}

Hip-hop music which was believed to have been originally created to inform, advocate and educate the man, has drastically deviated from the intension and has since then faced so much negative criticisms as to immoral way of life it now champions and encourages today. The exhibition of violence, nudity, drug addiction and vulgar language has become the order of the day amongst youths. It is recommended that Hip-hop artistes should serve as positive role models for youths most especially the female gender in dressing, creativity, artistic expression and production of music that is educative in any dimension, which will positively contribute to societal development. The male hip-hop artists should be advised to discontinue objectifying female bodies in their music themes and music videos for commercial success. The music industry should avoid exposure on certain contents such as hip-hop music video that often carries negative implication for the cognitive and emotional health of youths, they should produce videos with positive themes on drug avoidance, sexual abstinence and good morals that will educate the undergraduate and society. The Performing Musicians Association of Nigeria (PMAN) and the censors' board in Nigeria should professionalize and do more in 
their duties of checkmating the hip-hop music works before dissemination to the public

Chukwuma, Marian Edohan

Postgraduate Student of the Department of Music, Nnamdi Azikiwe University Awka.

Agatha Onwuekwe

Professor of Music Department of Music, Nnamdi Azikiwe University Awka. 


\section{References}

Adedeji, F. (2010). Transformative musicology: Recontextualizing art music composition for societal transformation in Nigeria. Revista Electronica de Musicological Vol XIV. 25-50

Alim, H. S. (2006). Hip-hop as a culturally sustaining pedagogy in teaching and learning for Educational justice: New York. College press.

Collins, A. (2004). The effects of teenage motherhood on young adult outcome. Retrieved from www.cdc.gov .May $18^{\text {th }}$.

Esimone, C. C. (2012). Music in early childhood education: A study of selected pre-primary chools in Anambra state, Nigeria. Unpublished Ph.D. Thesis, presented at the Nnamdi Azikiwe University, Awka, Anambra state, Nigeria.

Forbes, C. (2010). Does exposure to sexual hip-hop music videos influence the sexual attitudes of College students. Journal of Music Philosophy, 13(1), 14-17.

Glennon, O. (2017). Hip-hop language in sociolinguistic and beyond. Language and Linguisti Compass, 1(5), 5-23.

Gluck, C. (2005). Music analyzing in entertaining life cycles's principles and perspective: Journal of Mass Media Studies, 45(4), 116-124.

Idolor, G. E. (2002). The theorist and the performer in music practice. In E. Idolor (Ed.), Music in Africa: Facts and Illusions (pp.54-63). Ibadan: Stirling -Horden Publishers.

Okafor, R. C. (1994). The Musician in the Nigerian Society. Journal of Research in General Studies, 2, 97110.Republished in 2001, Dynamics of social studies, 
Chikelue Ofuebe (Ed) Enugu: New Generation Books, 143161.

Okeke, I. N. (2009). The impact of pop-music on Nigerian youths:.A Post graduate diploma. project presented at the Nnamdi Azikiwe University, Awka, Anambra state, Nigeria.

Omibiyi-Obidike, M. A (1994). New horizons in Nigerian popular music. A paper presentated at the mini- Conference PANAFEST 94, International Centre for African Music and Dance (December $13^{\text {th }}-14^{\text {th. }}$.

Onwuekwe, A. I. (2004). The socio-cultural implication of African music and dance. Journal of Theatre and media studies 3 (1) 20-28.

Spradlin, E. (2016). The rap music attitude and perception (RAP) scale: scale development and Preliminary analysis of psychometric properties. Journal of Human Behavior in the Social Environment, 11(3/4), 49-82.

Tanner \& Worley (2016). Student perceptions of the hip-hop culture's influence on the Undergraduate experience. Journal of College Student Development, 52(2), 8-17.

Travis, R. (2011). Rap music and the empowerment of today's Youth. Child \& Adolescent Social Work Journal, 30(2), 139-167. 